\title{
Lipotropin, Melanotropin and Endorphin: In Vivo Catabolism and Entry into Cerebrospinal Fluid
}

\author{
P. D. PEZALLA, M. LIS, N. G. SEIDAH AND M. CHRÉTIEN
}

\begin{abstract}
SUMMARY: Anesthetized rabbits were given intravenous injections of either beta-lipotropin (beta-LPH), betamelanotropin (beta-MSH) or betaendorphin. The postinjection concentrations of these peptides in plasma and cerebrospinal fluid (CSF) were measured by radioimmunoassay $(R I A)$. The plasma disappearance half-times were $13.7 \mathrm{~min}$ for beta-LPH, 5.1 min for beta-MSH, and $4.8 \mathrm{~min}$ for beta-endorphin. Circulating beta- $L P H$ is cleaved to peptides tentatively identified as gamma-LPH and beta-endorphin. Each of these peptides appeared in the CSF within 2 min postinjection. The maximum CSF to plasma ratios were 0.08 for beta- $L P H, 1.48$ for beta-MSH, and 0.23 for beta-endorphin.
\end{abstract}

RÉSUMÉ: Les lapins anesthésiés reçurent des injections intraveineuses, soit de béta-lipotropine (béta-LPH), de béta-mélanotropine (béta-MSH) ou de béta-endorphine. Les concentrations de ces peptides dans le plasma et le liquide céphalorachidien $(L C R)$ à la suite de ces injections furent mesurées par des essais radioimmunologiques (RIA). Les demitemps plasmatiques de disparition furent de $13.7 \mathrm{~min}$ pour la béta-LPH, $5.1 \mathrm{~min}$ pour la béta-MSH, et $4.8 \mathrm{~min}$ pour la béta-endorphine. La béta-LPH circulante est dégradée et les produite de dégradation initials sont tentativement identifées comme étant le béta-endorphine et la gamma-LPH. Chacun de ces peptides apparait dans le LCR dans les 2 minutes qui suivent l'injection. Le rapport maximum de concentration dans le LCR par rapport aux les taux plasmatiques était de 0.08 pour la béta-LPH, 1.48 pour la béta-MSH et 0.23 pour la béta-endorphine.

From the Clinical Research Institute of Montreal, Affiliated to the Université de Montréal and the Hôtel-Dieu de Montreal.

Reprint requests to: Dr. P. D. Pezalla, Clinical Research Institute of Montreal, 110 avenue des Pins ouest, Montreal, Quebec H2W IR7, Canada.

\section{INTRODUCTION}

Beta-lipotropin (beta-LPH) is a peptide of 91 amino acids that was first isolated from ovine pituitary glands (Li et al., 1965). Although beta-LPH has a number of physiological actions including the stimulation of lipolysis and melanophore dispersion, it is believed to function principally as a prohormone for betamelanotropin (beta-MSH) and betaendorphin. Beta-MSH, which comprises the sequence 41-58 of betaLPH, is considerably more potent than beta-LPH in either lipolytic or melanophore stimulating assays (Chrétien, 1973). In addition, the active heptapeptide core of beta-MSH exhibits both behavioral and electroencephalographic actions in the rat and man (Kastin et al., 1976c). The second peptide for which betaLPH is believed to be the prohormone is beta-endorphin. This peptide corresponds to the sequence 61-91 of beta-LPH and, like betaMSH, has both central and peripheral actions. Beta-endorphin is produced in the pars intermedia (LaBella et al., 1976; Queen et al, 1976; LaBella et al., 1977; Crine et al., 1977) and is well known for its potent opiate-like actions on the central nervous system and on peripheral neuromuscular transmission (reviewed by Goldstein, 1976; Goldstein and Cox, 1977; Scherrer et al., 1977).

An important question that has not been directly addressed is whether beta-MSH and beta-endorphin can cross the blood-brain barrier to reach their putative site of action, the central nervous system. Beta-MSH has been found in CSF (Smith and Shuster, 1976) and peripherally administered beta-MSH can increase protein synthesis in certain brain regions
(Rudman et al., 1974). These findings suggest, albeit weakly, that the peptide might cross the blood-brain barrier. In the case of beta-endorphin, there are physiological studies both supporting and negating the possibility that beta-endorphin crosses the blood-brain barrier. The study of Tseng et al. (1976) supports this possibility since they observed analgesia in mice following intravenous injection of beta-endorphin. However, Pert et al. (1976) were unable to elicit central effects in rats by intravenous injection of the smaller, proteolytic enzyme resistant analogue (D-Ala ${ }^{2}$-Met-enkepalinamide and surmised that it did not cross the blood-brain barrier.

The goals of this study were (a) to determine if beta-LPH, beta-MSH and beta-endorphin could cross the blood-brain barrier of the rabbit, (b) to estimate their half-lives in the circulation and (c) to determine if the prohormone, beta- $\mathrm{LPH}$, is cleaved in vivo to one or both of its constituent hormones.

\section{MATERIALS AND METHODS}

Animals: Male New Zealand white rabbits $(2-3 \mathrm{~kg})$ were anesthetized by intraperitoneal injection of 5-7 $\mathrm{g}$ of urethane in $10-14 \mathrm{ml}$ of $0.9 \% \mathrm{NaCl}$. After anesthesia had been induced, blood and CSF samples were taken simultaneously. Blood $(0.5-1 \mathrm{ml})$ was allowed to drop from a small cut in a marginal ear vein into a tube containing EDTA. The blood was immediately cooled on ice, centrifuged and the plasma stored at $-20^{\circ} \mathrm{C}$. CSF $(0.1-0.2 \mathrm{ml})$ was taken from the cisterna magna with a 23 -gauge $3 \frac{1}{2}$ inch spinal needle inserted percutaneously. The needle was equipped with an occluding stylet that was kept in place between samplings. The CSF 
was frozen in a dry ice-ethanol bath immediately after withdrawal. CSF samples were judged to be free of contamination by blood if they were clear and colorless. Injections of the test substances were made $15 \mathrm{~min}$ after the first sample was taken. Twenty nmoles of either beta-LPH, beta-MSH or beta-endorphin in 0.5 $\mathrm{ml}$ of $0.9 \% \mathrm{NaCl}$ were injected into the marginal vein of the ear not used for blood sampling. The injections took about $1 \mathrm{~min}$. Four rabbits received each peptide and an additional four received saline alone. Each rabbit was used only once.

Peptides: Ovine beta-LPH, beta-LPH $\mathrm{L}_{-47}$ and beta-endorphin and porcine beta-MSH were purified as previously described (Chrétien et al., 1976; Li et al., 1965; Pezalla et al., in press). The peptides for injection as well as for RIA iodination and standardization were purified to homogeneity as determined by electrophoresis and amino acid analysis.

RIA: The details of our procedure for RIA have been described (Pezalla et al., In Press). Antisera against beta-MSH and beta-LPH were raised in this laboratory. Antiserum against beta-endorphin was generously supplied by Dr. Roger Guillemin. The anti-beta-MSH serum cross reacts with both beta- and gamma-LPH (47\% and $31 \%$ respectively on a molar basis). The anti-beta-LPH serum was used with beta-LPH 1-47
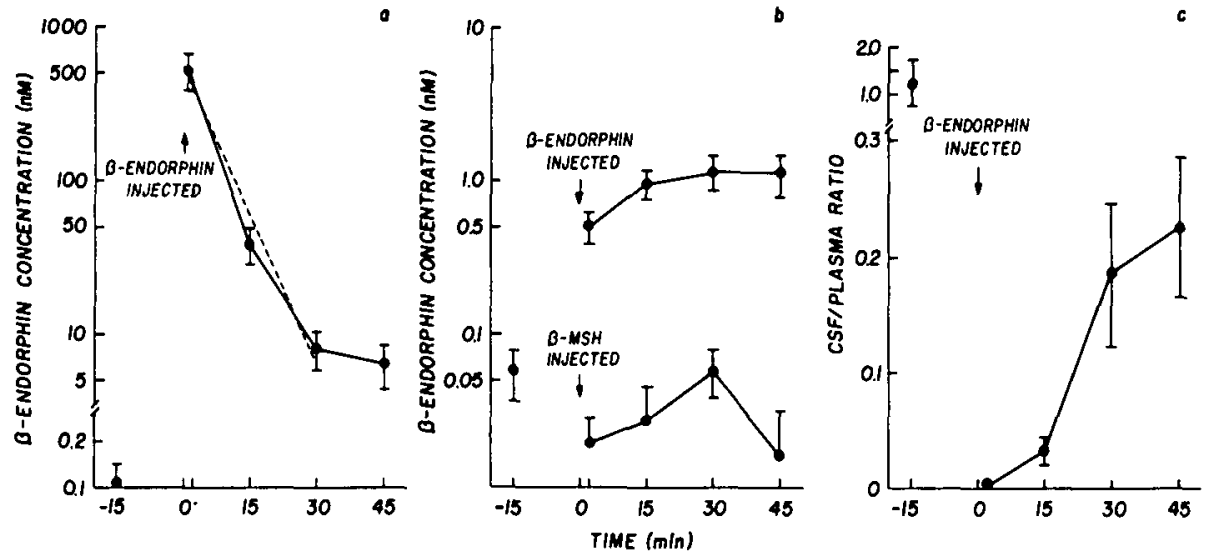

Figure 1-The fate of exogenous beta-endorphin in vivo. a. Disappearance rate of plasma beta-endorphin. The dashed line is the least squares regression from which a half-life of 4.8 min was calculated. b. Concentration of beta-endorphin in CSF after intravenous injection of beta-endorphin or beta-MSH. c. CSF to plasma ratios of beta-endorphin. Data expresses as mean \pm standard error of the mean.
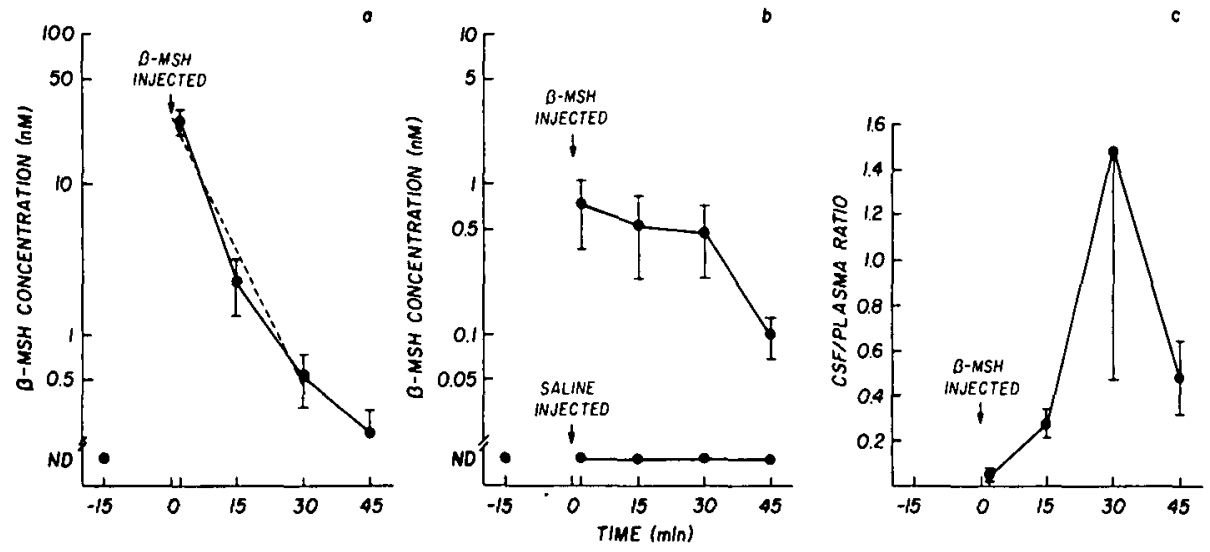

Figure 2-The fate of exogenous beta-MSH in vivo. a. Disappearance rate of plasma beta-MSH. The calculated half-life was $5.1 \mathrm{~min}$. b. Concentration of beta-MSH in CSF after intravenous injection of beta-MSH or saline. c. CSF to plasma ratios of beta-MSH. Data expressed as in Fig. 1. ND = not detectable.

as tracer and standard. Under these conditions, beta-LPH and gammaLPH cross react $46 \%$ and $79 \%$ while beta-MSH does not cross react. The anti-beta-endorphin serum cross reacts $58 \%$ with beat-LPH and not at all with gamma-LPH or betaMSH. More complete characterizations of the antisera can be found in Guillemin et al (1977) and Pezalla et al (in press).

Chromatography: Gel filtration chromatography was done at $4^{\circ} \mathrm{C}$ on 1 x $42 \mathrm{~cm}$ columns of Sephadex G-50 superfine (Pharmacia). The columns were equilibrated and eluted with $\mathrm{pH}$ 7.6 phosphate buffered saline containing $25 \mathrm{mM}$ EDTA and $1 \%(\mathrm{w} / \mathrm{v})$ bovine serum albumin (Pezalla et al., in press). One $\mathrm{ml}$ fractions were collected and stored frozen. The columns were calibrated with ${ }^{125} \mathrm{~J}$-labelled beta-LPH, beta-MSH and beta-endorphin.

\section{RESULTS}

Concentrations of immunoreactive beta-endorphin in the preinjection samples of plasma and CSF were near or below the limits of detectability. For those animals which had measurable beta-endorphin in both CSF and plasma, the concentration ratios were between 0.43 and 2.70 . No apparent correlation between the levels in the two fluids was seen, possibly because of the error in measuring such low concentrations. The mean half-time of disappearance from the plasma was $4.8 \mathrm{~min}$ (Fig. 1a).

Beta-endorphin appears in the CSF within 2 min after injection. The concentration $(0.5 \mathrm{nM})$ is nearly ten times the preinjection level. The concentration is maximal and does not change significantly between 15 and $45 \mathrm{~min}$ (Fig. Ib). The stability of beta-endorphin in CSF as opposed to plasma is responsible for the continued rise in the CSF to plasma concentration ratio. The maximum ratio $(0.23 \pm 0.06)$ was seen at $45 \mathrm{~min}$ (Fig. 1c). Beta-endorphin in the CSF of control (beta-MSH injected) rabbits remained low or undetectable (Fig. 1b).

Immunoreactive beta-MSH was undetectable in all preinjection samples of both plasma and CSF. At $2 \mathrm{~min}$ 
post-injection, the mean plasma concentration was $26 \pm 4 \mathrm{nM}$. This is an order of magnitude less than the 2 min concentrations of either betaendorphin or beta-LPH, which were injected at the same dose. Between 2 and $30 \mathrm{~min}$ beta-MSH disappeared with an apparent half-time of $5.1 \mathrm{~min}$ (Fig. 2a). The maximum concentration of beta-MSH in CSF $(0.72 \pm 0.35$ $\mathrm{nM}$ ) was observed at $2 \mathrm{~min}$. The level had declined slightly at 15 and $30 \mathrm{~min}$ and was only $0.10 \pm 0.03 \mathrm{nM}$ at $45 \mathrm{~min}$ (Fig. 2b). Beta-MSH remained undetectable in saline injected rabbit CSF. The CSF to plasma ratios for betaMSH were variable and reached a maximum of $1.48 \pm 1.75$ at $30 \mathrm{~min}$ (Fig. 2c). This high value is largely attributable to one animal in which a ratio of 3.48 was calculated.

The preinjection concentration of plasma beta-LPH averaged $0.12 \pm 0.03 \mathrm{nM}$. Beta-LPH was undetectable in two of four of the preinjection CSF samples and was only 0.08 and $0.14 \mathrm{nM}$ in the other two samples. The apparent half-life of beta-LPH in the circulation was 13.7 min, considerably longer than that of beta-endorphin or beta-MSH (Fig. $3 a)$. The concentration of beta-LPH in CSF as well as the CSF to plasma ratio, continued to increase for the duration of the experiments. The maximum concentration $(5.5 \pm 0.7$ $\mathrm{nM})$ and the maximum ratio $(0.080 .03)$ were at $45 \mathrm{~min}$ (Fig. 3b, c). The controls for the betaendorphin (Fig. Ib) and beta-MSH (Fig. 2b) experiments also apply to beta-LPH. Any increase in the control levels of beta-LPH would have been detected with either the antendorphin or anti-MSH serum. The pooled plasma samples for each time period were fractionated on Sephadex G-50 and each fraction was assayed for immunoreactive (IR) $\mathrm{N}$-fragment, beta-MSH and betaendorphin. We also calculated the approximate concentration of "gamma-LPH" in each fraction by subtracting the concentration of IRendorphin from the concentration of IR-N-fragment (i.e. if a tube contains a molar excess of $\mathrm{N}$-fragment over beta-endorphin, we tentatively assume that to represent gamme-LPH). The results are shown in Fig. 4. At 2 min after the injection of beta-LPH, the majority of the IR-LPH, -MSH, and -endorphin eluted with beta-LPH (Fig. 4 a, b, c), but there was also a clear peak of IR-endorphin eluting near standard beta-endorphin (Fig. 4c). The calculated "gamma-LPH" peak in tubes 16-18 (shaded area) is approximately equal to the betaendorphin peak (tubes 19-21, Fig. $3 \mathrm{c})$. At $15 \mathrm{~min}$, the IR-N-fragment, -MSH and -endorphin all appeared in two peaks (Fig, 4d, e, f). In each case the first peak coincides with that of standard beta-LPH and is taken to be the intact molecule. In addition, the second peak of IR-endorphin elutes with standard endorphin (Fig. 4f) while the second peak of both
The final question addressed by this study concerns the nature of the IR-LPH found in the CSF. In order to determine if this was beta-LPH, gamma-LPH or $\mathrm{LPH}_{1-38}$, we fractionated the pooled 30 and $45 \mathrm{~min} \mathrm{CSF}$ samples on Sephadex G-50 as described for the plasma samples. IR-MSH elutes as two peaks in both the 30 and 45 min CSF samples (Fig. $5 a, c)$. The first peak coincides with beta-LPH and the second may represent gamma-LPH. IR-endorphin elutes principally as beta-LPH (Fig. $5 b, d)$. The identity and significance of the second peak of IR-endorphin seen at $30 \mathrm{~min}$ is unknown. No free beta-MSH or beta-endorphin were found.
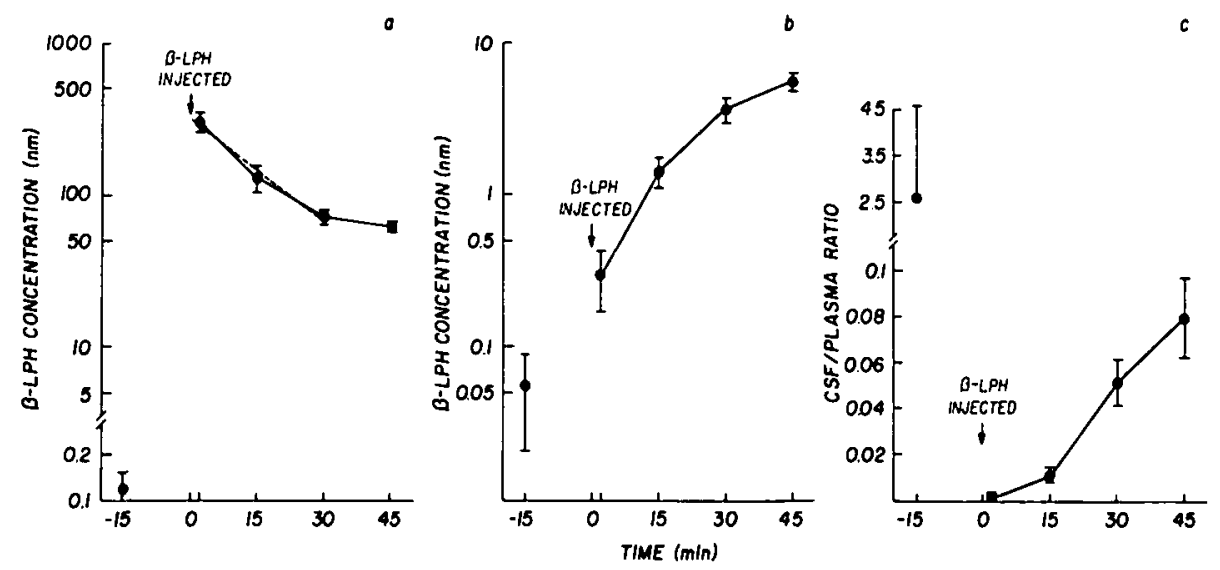

Figure 3-The fate of exogenous beta-LPH in vivo. a. Disappearance rate of plasma beta-LPH. The calculated half-life was $13.7 \mathrm{~min}$. b. Concentration of beta-L.PH in CSF after intravenous injection of beta-LPH. c. CSF to plasma ratios of beta-1.PH. Data expressed as in Fig. 1.

$\mathrm{N}$-fragment and beta-MSH can be accounted for as "gamma-LPH", calculated as above (Fig. 4 d, c). By 30 and $45 \mathrm{~min}$, an increasing fraction of the IR-N-fragment and-MSH can be accounted for as "gamma-LPH" rather than beta-LPH (Fig. $4 \mathrm{~g}-1$ ). In fact, at 45 min there is essentially no remaining beta- $\mathrm{LPH}$ as is evidenced by the paucity of IR-endorphin in fractions 14-16 (Fig. 41).

Since no IR-MSH was detected at the elution volume of beta-MSH, we conclude that beta-LPH was not transformed peripherally into betaMSH. This conclusion is supported by our iailure to find any IR-N fragment the size of beta- $\mathrm{LPH}_{1-38}$.

\section{DISCUSSION}

There is growing awareness that peptides related to ACTH and betaLPH can have profound effects on brain functions. The heptapeptide sequence that is common to ACTH, betaand gamma-LPH and beta-MSH has been shown to influence extinction of conditioned active, conditioned passive and appetitive responses (Kastin et al., 1973), reaction time Kastin et al., 1973), visual memory (Sandman et al., 1972) and attention and stimulus processing (Sandman et al., 1977). In addition, the endorphins and enkephalins which are believed to derive from beta-LPH are capable 
of inducing analgesia, catatonia (akinesia), sedation and excessive grooming (Belluzzi et al., 1976; Buscher et al., 1976; Graf et al., 1976; Gispen et al., 1976; Motomatsu et al., 1976; Bloom et al., 1976; Jacquet and Marks, 1976; Tseng et al., 1977; Bradbury et al., 1977). Our results show that beta-endorphin, betaMSH and beta-LPH can pass from the circulation to the CSF in the rabbit. The concentration of betaLPH in the CSF continued to increase for the duration of the experi- ment and reached the highest level of the three peptides tested. The physiological significance of this is uncertain since intact beta-LPH is not known to have central actions. A second peak of IR-MSSH was also found in the CSF of beta-LPH treated rabbits. We tentatively conclude that this represents "gamma-LPH" that has entered the CSF from the circulation, but cannot exclude the possibility that it is a cleavage product generated by the CSF or brain. Although we have shown that circulating

\section{N-FRAGMENT}
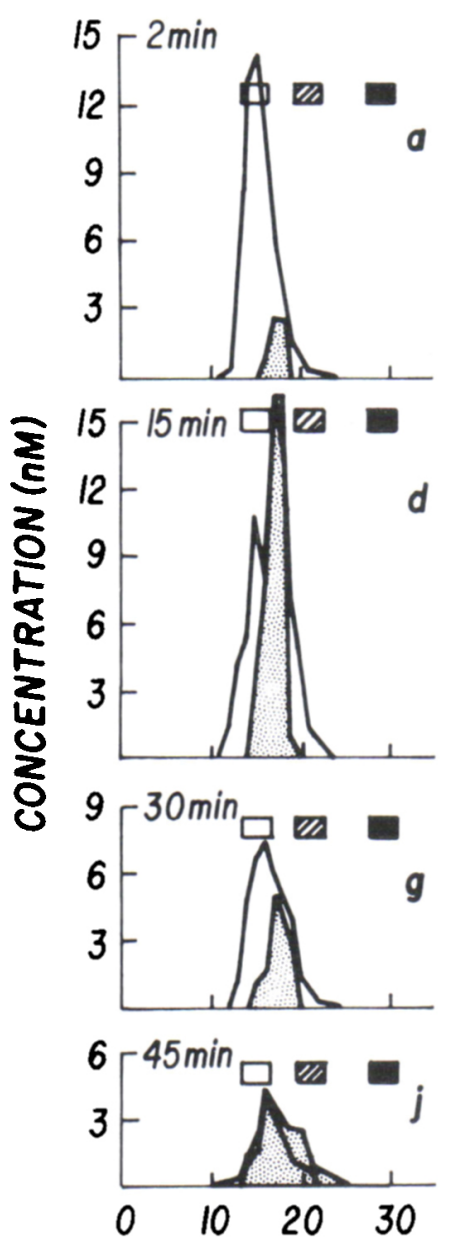

$B-L P H$
B-MSH
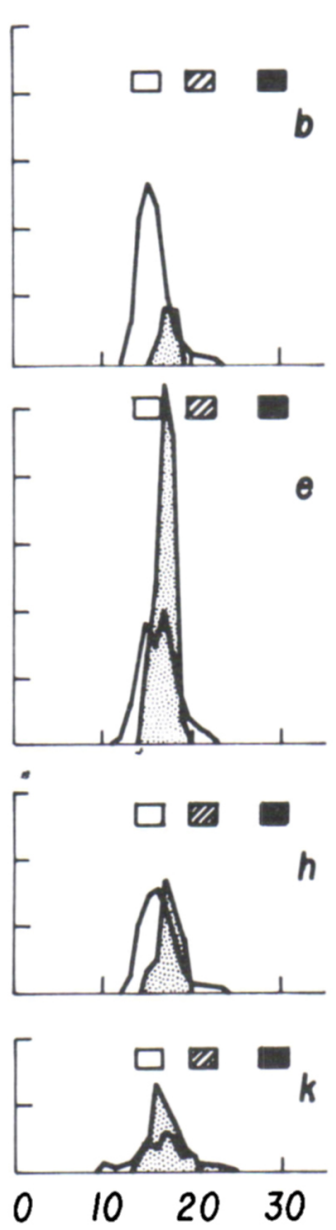

FRACTION NUMBER ( $\mid \mathrm{ml})$

\section{B-ENDORPHIN}
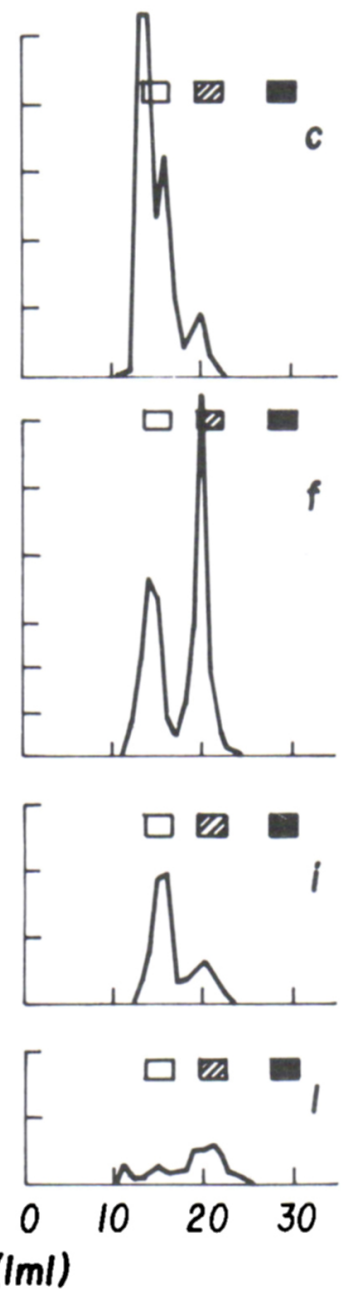

B-MSH

Figure 4-Immunoreactive $\mathrm{N}$-fragment (a, d, g, j), beta-MSH (b, e, h, k) and beta-endorphin $(\mathrm{c}, \mathrm{f}, \mathrm{i}, \mathrm{l})$ in plasma fractionated on Sephadex G-50. Plasma was collected 2, 15, 30 and 45 min after intravenous injection of 20 nmoles of beta-LPH. The shaded area indicates the calculated concentration of gamma-LPH (see text). The blocks indicate the elution positions of ${ }^{125} \mathrm{I}$-labelled beta-LPH, beta-endorphin, and beta-MSH. a, b, c, 2 min; d, e, f, 15 min; g, h, i, 30 min; j, k, l, 45 min.

beta-LPH is cleaved to betaendorphin in the circulation, we failed to detect beta-endorphin in the CSF of beta-LPH injected rabbits. This is undoubtedly due to the sensitivity of the method. Since only a very small volume of CSF was available for fractionation, we were unable to detect the anticipated trace quantities of beta-endorphin. The generation of beta-endorphin from circulating beta-LPH is of uncertain significance. It does not seem likely that, in physiological situations, a concentration of beta-endorphin sufficient to influence behavior would be attained.

Beta-MSH levels in the CSF were highest at $2 \mathrm{~min}$ post-injection. The decline that followed is likely a consequence of degradation or uptake by the brain rather than return to the circulation, since the blood levels remained higher (except in one sample) than CSF levels. Brain tissue is known to inactivate beta-MSH enzymatically (Long et al., 1961).

Since beta-MSH can influence behavior (Ferrari et al., 1963) and neuronal activity (Krivoy et al., 1977), our finding that it does pass from the circulation to the CSF may be of physiological importance. Smith and Shuster (1976) found high levels of immunoreactive beta-MSH in human CSF, a finding that further supports the possibility that this peptide may be involved in the regulation of central nervous system activity.

Physiological studies have yielded conflicting results concerning the transfer of endorphins and enkephalins from the circulation to the CSF (Pert et al., 1976; Plotnikoff et al., 1976; Tseng et al., 1976). Our demonstration that in certain species circulating beta-endorphin has access to the CSF supports the possibility that pituitary beta-endorphin is a functioning ligand for brain opiate receptors. Previously, Kastin et al. (1976b) showed that enkephalin crossed the blood-brain barrier of rats, a finding supported by our results with endorphin and the work of Plotnikoff et al. (1976).

Our results show that the three peptides tested can pass from the circulation to the CSF. Further studies are needed to determine the 
point or points of entry into the CSF. Oliver et al. (1977) have provided evidence that pituitary hormones are transported by retrograde blood flow from the pituitary toward the hypothalamus. It is possible that this vascular system delivers high concentrations of pituitary hormones to the CSF.

Accurate determinations of disappearance rates require more rapid and frequent sampling than was used in this study. Because our first samples were not taken until 2 min after the injection, we undoubtedly missed the early, rapid phase of the disappearance curves. This is especially apparent in the case of beta-MSH. Nonetheless, our results do show that beta-MSH and beta-endorphin are rapidly cleared from the circulation. Kastin et al. (1976a, b) found the half-time disappearance of alphaMSH and enkephalin to be $1.5 \mathrm{~min}$ or less for the early component of the disappearance curve. In addition, for enkephalin the second component of the curve gave a half-time of $4.8 \mathrm{~min}$, a value quite close to those for beta-MSH and beta-endorphin.

The long apparent half-time for the disappearance of beta-LPH is probably related to the specificity of the antiserum used. The antiserum recognizes the $\mathrm{N}$-terminal portion of beta-LPH and gamma-LPH. By gel filtration and RIA we have shown that the catabolism of beta-LPH begins at the C-terminus (Fig. 4). Within 2 min after administration, beta-LPH is partially cleaved to peptides tentatively identified as betaendorphin and gamma-LPH by molecular weight and immunological characterization. These techniques are obviously not adequate to determine the exact position of the cleavage. However, in view of the known lability of the peptide bond between arginine (position 60) and tyrosine (position 61) of beta-LPH to trypsin and trypsin-like enzymes (Bradbury et al., 1976; Seidah et al., 1977) it seems likely that cleavage occurs at this point. Furthermore, the $\mathrm{N}$-terminal tyrosine of betaendorphin is quite resistant to aminopeptidases and to brain enzymes (Austen and Smyth, 1977; Marks et al., 1977). Thus, it is un- likely that the active $\mathrm{N}$-terminus of beta-endorphin is removed. We found no evidence for the in vivo cleavage of beta- or gamma-LPH to beta-MSH. It appears the circulating beta-LPH may serve as a source of beta-endorphin but not beta-MSH.

This report provides the first direct evidence that beta-LPH, beta-MSH and beta-endorphin can pass from the circulation to the CSF and that circulating beta-LPH can be cleaved to beta-endorphin. Our findings provide additional support for the notion that these pituitary peptides may have physiological actions on the central nervous system.

\section{ACKNOWLEDGMENTS}

This work was supported by a Medical Research Council of Canada Program Grant and the Edwards Foundation. We thank Mrs. Marie-Claude Guérinot for the cheerful and skilled technical assistance and Mrs. D. Marcil for typing the manuscript.

\section{REFERENCES}

AUSTEN, B. M. and SMYTH, D. G. (1977), The NHz-terminus of C-fragment is resis-

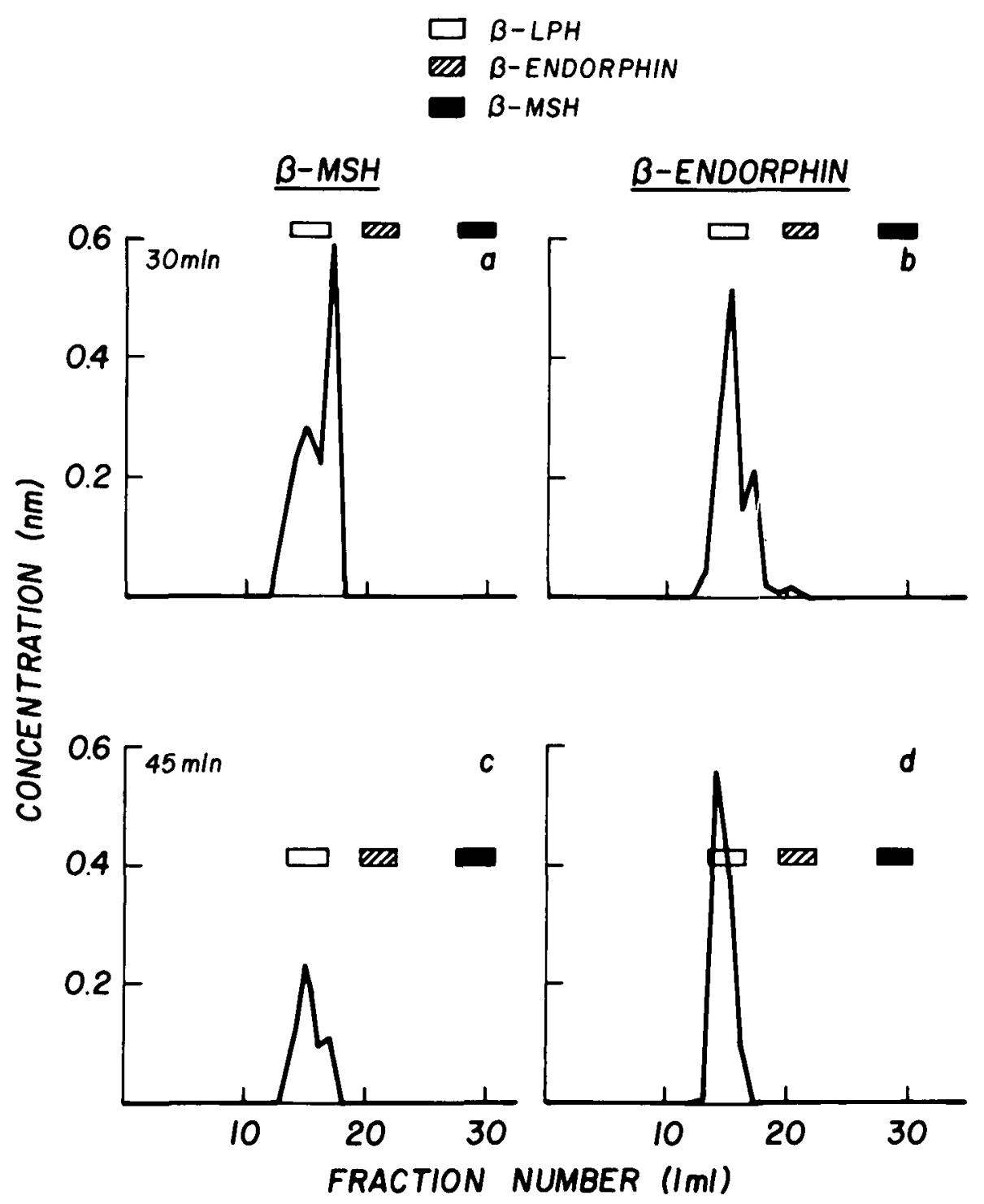

Figure 5-Immunoreactive beta-MSH (a, c) and beta-endorphin (b, d) in CSF fractionated on Sephadex G-50. CSF was collected 30 and 45 min after intravenous injection of beta-LPH. The elution positions of ${ }^{125} \mathrm{I}$-labelled beta-LPH, beta-endorphin, and beta-MSH are indicated by the blocks. a, b $30 \mathrm{~min}$; c, d, $45 \mathrm{~min}$. 
tant to the action of aminopeptidases. Biochemical and Biophysical Research Communications 76, 477-482.

BELLUZZI, J. D., GRANT, N., GARSKY, V., SARANTAKIS, D., WISE. C. D. and STEIN, L. (1976). Analgesia induced in vivo by central administration of enkephalin in rat. Nature 260, 625-626.

BLOOM, F., SEGAL, D., LING, N. and GUILLEMIN, R. (1976). Endorphins: Profound behavioral effects in rats suggest new ethiological factors in mental illness. Science 194. 630-632.

BRADBURY, A. F., SMYTH, D. G. and SNELL. C. R. (1976). Lipotropin: precursor to two biologically active peptides. Biochemical and Biophysical Research Communications 69, 950-956.

BRADBURY, A. F., SMYTH, D. G., SNELL, C. R., DEAKIN, J. F. W. and WENDLANDT, S. (1977). Comparison of the analgesic properties of lipotropin $C$-fragment and stabilized enkephalins in the rat. Biochemical and Biophysical Research Communications 74, 748-754.

BUSCHER, H. H., HILL, R. C., ROMER, D., CARDINAUX, F.. CLOSSE, A., HAUSER, D. and PLESS, J. (1976). Evidence for analgesic activity of enkephatin in the mouse. Nature 261, 423-425.

CHRÉTIEN. M. (1973). Lipotropins. In: Methods in Investigative and Diagnostic Endocrinology (Berson, S. A. and Yalow. R. S.. eds.) pp. 617-632, North Holland Publishing Co., Amsterdam.

CHRÉTIEN, M., BENJANNET, S., DRAGON, N., SEIDAH, N. G. and LIS, M. (1976). Isolation of peptides with opiate activity from sheep and human pituitaries: Relationship to beta-lipotropin. Biochemical and Biophysical Research Communications, 72, 472-478.

CRINE, P., BENJANNET, S., SEIDAH, N. G. LIS. M. and CHRÉ TIEN, M. (1977). In vitro biosynthesis of beta-endorphin. gamma-lipotropin and beta-lipotropin by the pars intermedia of beef pituitary glands. Proceedings of the National Academy of Science, USA 74, 4276-4280.

FERRARI, W., GESSA, G. L. and VARGIN, L. (1963). Behavioral effects induced by intracisternally injected $\mathrm{ACTH}$ and MSH. Annals of the New York Academy of Sciences, 104, 330-343.

GISPEN, W. H., WIEGANT, V. M., BRADBURY, A. F., HULME, E. C., SMYTH, D. G. and SNELL, C. R. (1976). Induction of excessive grooming in the rat by fragments of lipotropin. Nature 264, 794-795.

GOLDSTEIN, A. (1976). Opioid peptides (endorphins) in pituitary and brain. Science 193, 1081-1086.

GOLDSTEIN, A. and COX, B. M. (1977). Opioid peptides (endorphins) in pituitary and brain. Psychoneuroendocrinology 2, 11-16.

GRAF, L., SZEKELY, J. I., RONAI, A. Z., DUNAI-KOVACS, $Z$., and BAJUSZ, $S$. (1976). Comparative study on analgesic effect of Met $^{5}$-enkephalin and related lipotropin fragments. Nature 263, 240-241.
GUILLEMIN, R., LING, N. and VARGO, T. (1977). Radioimmunoassays for alphaendorphin and beta-endorphin. Biochemical and Biophysical Research Communications, 77, 36I-366.

JACQUET, Y. F. and MARKS, N. (1976). The C-fragment of beta-lipotropin: An endogenous neuroleptic or antipsychotogen. Science 194, 632-635.

KASTIN, A. J., MILLER, L. H., NOCKTON, R., SANDMAN, C. A., SCHALLY, A. V. and STRATTON, L. O. (1973). Behavioral aspects of MSH. Progress in Brain Research 39, 468-470.

KASTIN, A. J., NISSEN, C., NIKOLICS, K., MEDZIHRADSZKY, K., COY, D. H., TEPLAN, I. and SCHALLY, A. V. (1976a). Distribution of ${ }^{3} \mathrm{H}$-alpha-MSH in rat brain. Brain Research Bulletin 1, 19-26.

KASTIN, A. J., NISSEN, C., SCHALLY, A. V. and COY, D. H. (1976b). Blood-brain barrier, half-time disappearance, and brain distribution for labeled enkephalin and a potent analog. Brain Research Bulletin 1, 583-589.

KASTIN, A. J., SANDMAN, C. A., MILLER, L. H. and SCHALLY, A. V. (1976c). Some questions related to melanocytestimulating hormone. Mayo Clinic Proceedings. 51, 632-636.

KRIVOY, W., KROEGER, D., TAYLOR, A. N. and ZIMMERMANN, E. (1974). Antagonism of morphine by beta-melanocytestimulating hormone and by tetracosactin. European Journal of Pharmacology 27, 339-345.

KRIVOY, W. A., KROEGER, D. C. and ZIMMERMANN, E. (1977). Neuropeptides: Influence of acute and chronic effects of opiates. Psychoneuroendocrinology 21, 43-51.

LaBELLA, F., DOWNEY, G., QUEEN, G. and PINSKY, C. (1976). Endorphin activity in anterior, intermediate, and posterior pituitary. Canadian Journal of Physiology and Pharmacology 54, 946-948.

LaBELLA, F., QUEEN, G. and SENSYSHYN, J. (1977). Lipotropin: Localization by radioimmunoassay of endorphin precursor in pituitary and brain. Biochemical and Biophysical Research Communications 75, 350-357.

LI. C. H., BARNAFI, L., CHRÉTIEN, M. and CHUNG, D. (1965). Isolation and amino acid sequence of beta-LPH from sheep pituitary glands. Nature 208, 1093-1094.

LONG, J., KRIVOY, W. and GUILLEMIN, R. (1961). On a possible role of betamelanocyte stimulating hormone (beta$\mathrm{MSH}$ ) in the central nervous system of the mammalia: enzymatic inactivation in vitro of beta-M SH by brain tissue. Endocrinology $69,176-181$

MARKS, N., GRYNBAUM, A. and NEIDLE, A. (1977). On the degradation of enkephalins and endorphins by rat and mouse brain extracts. Biochemical and Biophysical Research Communications 74, 1552-1559.
MOTOMATSU, T., LIS, M., SEIDAH, N. G. and CHRÉTIEN, M. (1976). Cataleptic effect of 61.91 beta-lipotropin in rat. Clinical Research 24, 660A.

OLIVER, C., MICAL, R. S. and PORTER, J. C. (1977). Hypothalamic-pituitary vasculature: Evidence for retrograde blood flow in the pituitary stalk. Endocrinology 101, 598-604.

PERT, C. B., PERT, A., CHANG, J. K and FONG, B. T. W. (1976). (D-Ala ${ }^{2}$ )-Met-enkephalinamide: $A$ potent, long-lasting synthetic pentapeptide analgesic. Science 194, 330-332.

PEZALLA, P. D., CLARKE, W. C., LIS, M. and CHRÉTIEN, M. (1978). I mmunological characterization of beta-lipotropin fragments (endorphin, beta-MSH and $\mathrm{N}$-fragment) from fish pituitaries. General and Comparative Endocrinology (in Press).

PLOTNIKOFF, N. P., KASTIN, A. J., COY, D. H., CHRISTENSEN, C. W., SCHALLY, A. V. and SPIRTES, M. A. (1976). Neuropharmacological actions of enkephalin after systemic administration. Life Sciences 19, 1283-1288.

QUEEN, G., PINSKY, C. and LaBELLA, F. (1976). Subcellular localization of endorphin activity in bovine pituitary and brain. Biochemical and Biophysical Research Communications 72, 1021-1027.

RUDMAN, D., SCOTT, J. W., DEL RIO, A. E., HOUSER, D. H. and SHEEN, S. (1974). Effect of melanotropic peptides on protein synthesis in mouse brain. American Journal of Physiology, 226, 687-692.

SANDMAN, C. A., GEORGE J., MCCANNE, T, R., NOLAN, J. D., KASWAN, J. and KASTIN, A. J. (1977). MSH/ACTH 4-10 influences behavioral and physiological measures of attention. Journal of Clinical Endocrinology and Metabolism 44, 884-891.

SANDMAN, C. A., MILLER, L. H., KASTIN, A. J. and SCHALLY, A. V. (1972). Neuroendocrine influences on attention and memory. Journal of Comparative Physiological Psychology 80, 54-58.

SCHERRER, H., LIS, M., SEIDAH, N. G. and CHRÉ TIEN, M. (1977). Hypophyse et peptides morphinomimétiques. Union Méd. Can. 106, 542-552

SEIDAH, N. G., LIS, M., GIANOULAKIS, C., ROUTHIER, R., BENJANNET, S. SCHILLER, P. W. and CHRÉTIEN, M. (1977). Morphine-like activity of sheep beta-lipotropin and its tryptic fragments. Canadian Journal of Biochemistry 55, 35-40.

SMITH, A. G., and SHUSTER, S. (1976). Immunoreactive beta-melanocytesstimulating hormone in cerebrospinal fluid. The Lancet 1, 1321-1322.

TSENG, L. F., LOH, H. H. and Ll, C. H. (1976). Beta-endorphin as a potent analgesic by intravenous injection. Nature 263, 239-240.

TSENG, L. F., LOH, H. H. and LI, C. H. (1977). Human beta-endorphin: Development of tolerance and behavioral activity in rats. Biochemical and Biophysical Research Communications. 74, 390-396. 